\title{
Jarząbek Jarosław, Militaryzacja subregionu Zatoki Perskiej w perspektywie teorii regionalnych kompleksów bezpieczeństwa, Wydawnictwa Uniwersytetu Warszawskiego, Warszawa 2019, ss. 234 \\ (Radosław Zarzecki)
}

Problematyka państw Bliskiego Wschodu zajmuje badaczy od dziesięcioleci. W regionie tym, w którym niestabilność polityczna zdaje się być zjawiskiem chronicznym, znajdują się największe złoża ropy naftowej na świecie. Wciąż rosnące zapotrzebowanie na paliwa kopalne, szczególnie wśród krajów rozwiniętych, w sposób istotny podniosło znaczenie państw wchodzących w skład subregionu Zatoki Perskiej. Swobodny i bezpieczny dostęp do złóż, a także eksport ropy naftowej oraz gazu ziemnego, z kwestii państwowej i regionalnej, stał się zagadnieniem polityki światowej. Charakterystyka subregionu Zatoki Perskiej polega również na skomplikowanej sieci antagonizmów, które napędzają wewnętrzną rywalizację między państwami. Większość krajów Zatoki znajduje się w stanie wojny, prowadzi działania zbrojne, bądź doświadczyła konfliktu w niedalekiej przeszłości. Reszta, której wojna nie dotyka w sposób bezpośredni, obawia się, iż może się to zmienić w najbliższej przyszłości. Stąd też państwa te, uzyskując spore przychody z posiadanych bogactw naturalnych, inwestują miliardy dolarów rocznie w zbrojenia.

Jarosław Jarząbek w swojej książce Militaryzacja subregionu Zatoki Perskiej $w$ perspektywie teorii regionalnych kompleksów bezpieczeństwa w wyczerpujący sposób opisuje wymiar postępującego zbrojenia się państw Zatoki Perskiej, a także ukazuje determinanty tego procesu. Autor swoje badania oparł o założenia teorii regionalnych kompleksów bezpieczeństwa, zaliczanej do tzw. szkoły kopenhaskiej w badaniach nad bezpieczeństwem, lecz dokonał rewizji niektórych założeń. Jak zostało słusznie zauważone, wydana w 2003 r. praca Barry’ego Buzzana i Ole Weavera Regions and Powers: The Structure of International Security, nie straciła kompletnie swojej użyteczności, lecz należy ją nieco zaktualizować i dostosować do bieżącej sytuacji w regionie Bliskiego Wschodu. Właśnie w pierwszym, teoretycznym rozdziale pracy, autor skupia się na tych zagadnieniach. W sposób szczegółowy i wyczerpujący przedstawione zostały założenia teorii regionalnych kompleksów bezpieczeństwa, a następnie obszary, które należy zrewidować. Ostatni, trzeci podrozdział poświęcony jest umiejscowieniu Bliskiego Wschodu w teorii 
regionalnych kompleksów bezpieczeństwa, ze szczególnym uwzględnieniem subkompleksu, jaki stanowią państwa Zatoki Perskiej.

Następny rozdział autor poświęcił kwestii wydatków wojskowych w subregionie. Ten wymierny wskaźnik, ze wszystkimi ograniczeniami, które zostały w pracy przytoczone, pokazuje proces militaryzacji regionu. Począwszy od analizy danych, autor przechodzi do opisu sytuacji ekonomicznej wśród krajów Zatoki Perskiej. Ukazuje on zarówno, w jaki sposób sytuacja gospodarcza przyczynia się do rozbudowy siły militarnej, a także jakim obciążeniem dla budżetów państw subregionu są wydatki na cele wojskowe. Autor zwraca uwagę na interesującą kwestię - mimo iż kraje Zatoki Perskiej przeznaczają na zbrojenia więcej procent PKB niż większość państw na świecie, to tylko jedno z nich rozwinęło własny przemysł zbrojeniowy na szerszą skalę. Reszta pozyskuje uzbrojenie od zagranicznych kontrahentów. W rozdziale tym znajdziemy charakterystykę problemów, z jakimi borykają się państwa subregionu, zarówno w kontekście samego pozyskiwania uzbrojenia, jak i jego eksploatacji oraz obsługi. Ostatni podrozdział stanowi podsumowanie kwestii wydatków zbrojeniowych dla bezpieczeństwa regionu.

Kolejna część pracy poświęcona jest bezpośrednio siłom zbrojnym wszystkich państw Zatoki Perskiej. Analiza potencjału militarnego każdego kraju jest oparta o cztery kategorie. Po pierwsze, autor skupia się na samej strukturze i zadaniach armii danego kraju. Następnie przechodzi do zagadnień związanych ze stanem osobowym i wyposażeniem danych sił zbrojnych. Dwa kolejne podrozdziały traktują natomiast o niemierzalnych czynnikach wpływających na siłę militarną oraz o zewnętrznej współpracy państw Zatoki Perskiej na polu wojskowym. Układ pracy umożliwia swobodne porównywanie wybranych państw, a w każdym podrozdziale fakty uzupełnione zostały o komentarz i wyjaśnienie autora. Dzięki zestawieniu twardych danych liczbowych z niemierzalnymi i zewnętrznymi czynnikami ukazany został pełen obraz potencjału militarnego wszystkich państw subregionu.

Czwarty, ostatni rozdział dotyczy wpływu bezpieczeństwa na militaryzację subregionu.

Aby lepiej zobrazować ten proces, rozdział został podzielony na cztery podrozdziały, opisujące poziomy zachodzącej interakcji - od globalnego, przez międzyregionalny i regionalny, aż do krajowego. Autor wskazał, iż z racji dynamicznego charakteru zjawiska bezpieczeństwa i niemożliwości przyporządkowania danego procesu do jednego z poziomów, podział ten nie zawsze będzie całkowicie odpowiadał rzeczywistości. Wydaje się jednak, że powyższa koncepcja była jak najbardziej słuszna, a zastosowanie takiego podziału ułatwiło usystematyzowanie zagadnienia, jak i jego odbiór. W rozdziale tym wyjaśnione zostało, jaki wpływ na militaryzację subregionu mają polityka światowa, konflikty, próby współpracy ponadnarodowej i uwarunkowania wewnętrzne państw. 
Pracę Jarosława Jarząbka należy traktować jako dobre źródło wiedzy, nie tylko o samym procesie militaryzacji państw Zatoki Perskiej, ale również o specyfice i złożoności relacji wewnątrz subregionu. Intensyfikacja zbrojeń w tej części świata jest bowiem odbiciem sytuacji gospodarczej, międzypaństwowych antagonizmów na wielu płaszczyznach, jak ingerencji zewnętrznych. Z racji tego, iż państwa Zatoki Perskiej są czołowymi producentami ropy naftowej, wszelkie procesy zachodzące w samym subregionie mają lub mogą mieć przełożenie na rynek tego surowca, a co za tym idzie gospodarkę całego świata. Na przestrzeni ostatnich pięćdziesięciu lat zagadnienie stabilności regionu Bliskiego Wschodu, ze szczególnym uwzględnieniem subregionu Zatoki Perskiej, wielokrotnie było częścią polityki mocarstw. Uzależnienie dziesiątek państw od ropy naftowej i gazu ziemnego, pochodzących z rejonu Zatoki Perskiej, w sposób znaczący oddziaływało na politykę nie tylko regionalną, ale także globalną.

Analiza procesów zachodzących na Bliskim Wschodzie, w tym w krajach Zatoki Perskiej, stanowi wyzwanie dla badaczy. Złożoność i wielopłaszczyznowość relacji o charakterze międzypaństwowym, regionalnym i globalnym, a także mnogość uwarunkowań wewnętrznych, ze szczególnym uwzględnieniem polityczno-społecznych, które determinują sytuację w omawianym subregionie, nierzadko stanowi realną przeszkodę na drodze do zrozumienia specyfiki regionu i zachodzących tam procesów. Tym samym bardzo ciężko znaleźć źródło informacji na temat charakterystyki Bliskiego Wschodu, które będzie jednocześnie przystępne w odbiorze, kompleksowe i merytoryczne. Choć mogłoby się wydawać, że tekstów naukowych traktujących o sytuacji państw Zatoki Perskiej, szczególnie w kontekście historii najnowszej, jest aż nadto, to jednak większość z nich ma charakter odtwórczy. Na tym polu praca Jarosława Jarząbka wyróżnia się nie tylko innowacyjnym ujęciem problemu, ale także wnikliwą analizą procesów często pomijanych przez innych badaczy. Trafny dobór teorii pozwolił autorowi uchwycić pełne spektrum determinantów problematyki bezpieczeństwa subregionu Zatoki Perskiej. Z pewnością jest to pozycja godna polecenia dla wszystkich badaczy zajmujących się problematyką bliskowschodnią i zagadnieniem bezpieczeństwa. 